\title{
pengambilan keputusan perawat dengan berfikir kritis dalam meningkatkan pengetahuan masyarakat tentang covid-19
}

\author{
Kiki Ramadhani
}

\section{Email: kikiirmdhn@gmail.com}

\section{Latar Belakang}

Akhir-akhir ini dunia sedang disibukkan dengan urusan satu pandemi, tidak terkecuali Indonesia. Masalah ini disebabkan oleh satu virus pemicu flu, batuk dan sesak nafas namun berakibat kematian. Virus ini bernama Corona, tepatnya COVID19 (Coronavirus Disease 2019). Minimnya pengetahuan dan pemahaman masyarakat tentang covid-19 akan berdampak besar kepada masyarakat itu sendiri. Maka dari itu peawat dapat memberikan edukasi tentang covid-19 kepada masyarakat baik masyarakat umum maupun masyarakat dengan penderita penyakit tertentu.

\section{Metode}

Metode yang digunakan dengan kajian pustaka terhadap beberapa referensi yang mendukung .Pembahasan ini mempelajari faktor-faktor yang mempengaruhi penerapan masyarakat untuk berpikir kritis dalam menghadapi kondisi pandemi covid-19 saat ini, dengan mengubah pengetahuan masyarakat untuk mematuhi protokol kesehatan dan mengatuhi bahaya covid 19.

\section{Hasil}

Berdasarkan hasil penelitian dari beberapa literature yang diambil didapatkan metode penelitian yang dapat meningkatkan kemampuan berpikir kritis masyarakat dalam mengambil sebuah keputusan untuk meningkatkan pengetahuan tentang covid-19 melalui edukasi dari perawat. Berdasarkan literature yang didapatkan bahwa cara berpikir kritis dapat dilakukan dengan cara menganalisis, mengkaji, mengeksplorasi berbagai literatur demi meningkatkannya sikap dalam berpikir kritis dalam melakukan pengambilan keputusan. Hal ini bertujuan agar sewaktu mengambil sebuah keputusan, perawat tidak salah memberikan pelayanan edukasi kepada masyarakat. Sebelum mengambil keputusan untuk mengedukasi masyarakat kemudian perawat mengumpulkan data sebanyak-banyaknya dengan mengasah pemikiran mereka dengan mengambil dsri berbagai literatur dan sumber 
terpercaya agar hasil yang didapat akurat sesuai dengan prosedur yang ada dalam mengedukasi masyarakat untuk meningkatkan pengetahuan tentang covid-19.

\section{Pembahasan}

Akhir-akhir ini dunia sedang disibukkan dengan urusan satu pandemi, tidak terkecuali Indonesia. Masalah ini disebabkan oleh satu virus pemicu flu, batuk dan sesak nafas namun berakibat kematian. Virus ini bernama Corona, tepatnya COVID19 (Coronavirus Disease 2019). Virus corona adalah virus yang menyebabkan penyakit mulai dari gejala ringan hingga berat. Terdapat dua jenis corona virus yang menimbulkan penyakit dengan gejala berat seperti Middle East Respiratory Syndrome (MERS) dan Severe Acute Respiratory Syndrome (SARS). Virus covid-19 dinamakan Sars-CoV-2. Virus ini ditularkan antara hewan dan manusia. gejala umum akibat infeksi Covid-19 seperti gangguan pernapasan akut yaitu demam, batuk dan sesak napas. Masa selama 5-6 hari dan masa inkubasi terpanjang hingga 14 hari. Pada penderita COVID-19 yang berat dapat menyebabkan beberapa penyakit seperti pneumonia, sindrom pernapasan akut, gagal ginjal, bahkan kematian. Ada beberapa masyarakat yang harus dilakukan pengawasan secara khusus yaitu pada Penderita penyakit tertentu (jantung, diabetes, ginjal dan penyakit lain), ibu hamil dan usia lanjut, mereka membutuhkan pengetahuan tentang seberapa kuat daya tahan tubuh dalam menghadapi virus, bagaimana cara meningkatkan kekebalan, tindakan yang harus diambil jika lingkungan sekitar ,serta bagaimana penanganan dini jika virus ini menyerang orang dengan kasus khusus. Hal ini dikarenakan meski dalam keadaan sehat, mereka dianggap memiliki daya tahan tubuh yang lebih rendah dibandingkan dengan kelompok masyarakat lainnya. selain itu masyarakat umum membutuhkan pengetahuan peningkatan imun, tindakan preventif dan cara pengobatan sesuai dengan latar belakang pekerjaan mereka. mereka tetap memerlukan perlakuan khusus saat wabah sedang melanda sekitar.dengan memberikan edukasi tentang tips meningkatkan daya tahan tubuh, berinteraksi dengan orang disekitar, cara menjaga kebersihan diri, cara menjaga psikis agar tidak mudah panik. Selain informasi kesehatan bagi diri sendiri, pusat informasi juga seyogyanya menyediakan informasi kesehatan bagi keluarga orang-orang yang memiliki riwayat sakit, keluarga lansia dan ibu hamil. Dengan demikian masyarakat dapat saling mengingatkan dan menjaga diri untuk tetap melindungi dari serangan corona. Aktivitas sehari hari dengan melibatkan anggota tubuh seperti mata, hidung, atau mulut dapat 
mempengaruhi tingkat kesehatan paru-paru. Kondisi ini berlaku tidak mengenal batas usia . Sebagai contoh udara kotor yang terhirup hidung atau terhisap oleh mulut ketika beraktivitas akan berdampak pada paru-paru. Hal ini yang terjadi pada penyebaran virus corona kepada manusia. Mata, hidung dan mulut yang telah terkontaminasi virus ini mengakibatkan paru-paru menjadi tidak sehat sehingga mudah flu, batuk dan sesak nafas. masyarakat umum dapat dilihat berdasarkan latar belakang sosial dan kepribadiannya masing-masing. Minimnya pengetahuan dan pemahaman masyarakat mengenai informasi yang valid tentang agen virus Corona dapat menimbulkan dampak sosial yang besar.

\section{- Upaya pencegahan yang dapat dilakukan}

Upaya pencegahan yang dapat dilakukan adalah dengan melakukan berbagai kegiatan, salah satunya adalah kegiatan penyuluhan untuk dapat edukasi tentang meningkat pengetahuan tentang covid-19 kepada seluruh masyarakat mengenai wabah virus corona di Indonesia. Pengetahuan dan pemahaman yang ilmiah dan akurat yang dimiliki perawat dapat dipercaya akan dapat membantu masyarakat untuk mudah melaksanakan himbuan dan arahan pemrintah guna menekan penyebaran Covid-19. Adapun kegiatan penyuluhan kesehatan untuk meningkatkan pengetahuan masyarakat agar dapat menghadapi dan melewati pandemic Covid-19 yaitu :

a) Sosialisasi Covid-19 dan Penyuluhan Kesehatan Sosialisasi Covid-19 .

Kegiatan ini dilakukan dengan memberikan penjelasan tentang virus corona dan asal virus korona secara alami. Selain itu, masyarakat juga dijelaskan secara mudah dan menarik mengenai cara virus masuk ke tubuh manusia, dampak kesehatan yang ditimbulkan dan factor-faktor yang dapat meningkatkan keparahan penyakit pada orang yang masuk virus corona-19 kedalam tubuhnya. Selain membekali masyarakat dengan pengetahuan tentang Covid-19, perlu juga diberikan pengetahuan tentang kunci penting untuk terhindar dari penularan/transmisi virus corona-19 yaitu pengetahuan tentang kesehatan dan pola hidup bersih dan sehat (PHBS). Pemberian materi tentang lingkungan dan kesehatan serta pola hidup bersih dan sehat akan membantu masyarakat terhindar dari Covid-19 dan penyakit infeksius lainnya. Penyuluhan kesehatan juga akan meningkatkan kesadaran masyarakat akan 
pentingnya menjaga lingkungan dan diri agar tetap sehat. Lingkungan yang sehat akan membuat merasa nyaman, tenang dan bahagia sehingga dapat menikmati hidup. tubuh yang sehat dapat juga diperoleh dengan mengkonsumsi makanan yang bersih dan sehat serta gizi yang lengkap . Tubuh sehat akan sangat sulit terinfeksi Covid-19 atau penyakit lainnya, karena tubuh yang sehat memiliki imunitas yang kuat.

b). Desinfeksi/Penyemprotan Lingkungan Kegiatan desinfeksi. Kegiatan ini bertujuan untuk melakukan sterilisasi lingkungan dari adanya virus yang ada disekitar lingkungan. Perawat mengajarkan bagaimana cara melakukan penyemprotan desinfeksi yang mematuhi standar kesehatan, cara membuat desinfeksi dengan menggunakan alat rumah tangga sederhana

Kemudian perawat mengedukasi masyarakat dengan memberikan pengetahuan tentang bagaimana cara pencegahan covid-19 yang dapat dilakukan masyarakat secara mandiri.

- Pencegahan COVID-19 yang dapat dilakukan masyarakat yaitu dengan :

1. mencuci tangan menggunakan air dan sabun,

kemudian perawat mengajarkan kepada masyarakan Cara mencuci tangan yang benar yaitu dengan menggunakan air mengalir dan sabun setidaknya 20 detik. cuci tangan dengan sabun dilakukan secara rutin, terutama sebelum memegang mulut, hidung dan mata, jika tidak ada fasilitas cuci tangan, dapat menggunakan cairan berbasis alcohol dan setelah mencuci tangan, tangan dikeringkan dengan menggunakan handuk atau tisu sekali pakai.

2. Waspada untuk menjaga jarak atau berkontak langsung dengan orang sakit.

3. menutup mulut dan hidung dengan tisu ketika batuk atau bersin

Etika batuk dan bersin yang diajarkan perawat yaitu dengan menggunakan masker ketika sedang flu atau batuk ,menutup hidung dan mulut dengan menggunakan tisu atau lengan dalam bagian atas, dan mencuci tangan dengan menggunakan air bersih dan sabun atau pencuci tangan berbasis alkohol setelah memegang tisu setelah batuk/bersin dan setelah 
menggunakan tisu, tisu langsung dibuang ke kotak sampah

4. menggunakan masker ketika memiliki gejala saluran napas.

Penggunaan masker yang benar yaitu masker dipakai dengan posisi menutupi hidung, mulut, dan dagu secara sempurna, dan membuang masker yang telah digunakan jika masker basah atau kotor, harus segera diganti dan melakukan cuci tangan setelah membuka masker.

\section{Penutup}

\section{Kesimpulan}

Sebagai perawat yang profesional harus berpikir kritis sebelum melakukan tindakan keperawatan atau asuhan keperawatan hal ini bertujuan agar sewaktu mengambil sebuah keputusan,perawat tidak salah memberikan pelayanan edukasi kepada masyarakat. perawat mengumpulkan data sebanyak-banyaknya dengan mengasah pemikiran mereka agar hasil yang didapat akurat seorang perawat akan mempunyai keberanian untuk mengambil keputusan dan memikul tanggung jawab dari keputusan yang telah diambilnya. Untuk mengambil suatu keputusan pun perawat tidak boleh asal asalan harus memperhatikan banyak hal yang nantinya akan menjadi keputusan yang akurat dan jelas dalam memberikan asuhan keperawatan maupun tindakan keperawatan.

\section{Saran}

Dalam meningkatkan kemampuan berpikir kritis perawat perlu adanya penyusunan dan pelaksanaan program pelatihan berpikir kritis untuk perawat demi meningkatnya kualitas keperawatan.

\section{Daftar Pustaka}

1. Anggun Wulandari, Fauzi Rahman, Nita Pujianti, Ayu Riana Sari, Nur Laily, Lia Anggraini, Farid Ilham Muddin, Agus Muhammad Ridwan, Vina Yulia Anhar, Muhammad Azmi Yannoor, dan Diki Bina Prasetyo. 2020. Hubungan Karakteristik Individu Dengan Pengetahuan Tentang Pencegahan Coronavirus Disease 2019 Pada Masyarakat di Kalimantan Selatan. Jurnal Kesehatan 
Masyarakat Indonesia, 15(1), 42-46

2. Handayani,Diah, Dwi Rendra Hadi, Fathiyah Isbaniah, Erlina Burhan, Heldy Agustin. 2020. Penyakit virus Corona 2020. Jurnal Respirologi Indonesia. $40(2), 1-14$.

3. Indriate. (2013). Berfikir Kriris dalamProses Keperawatan. JurnalKeperawatan, 6(2), 89-93.

4. Jesica Moudy, Risma Adelia Syakurah. 2020. Pengetahuan terkait Usaha Pencegahan Coronavirus Disease (COVID-19) di Indonesia. Higeia Journal of Public Health Research and Development, 4(3)

5. Muis,Afni Regita Cahyani. 2020. Tarsparansi kebijakan publik sebagai strategi nasional dalam menanggulangi pandemi Covid-19. Jurnal sosial dan budaya syar'i,7(5),1-18.

6. Nurislaminingsih,Rizki. 2020. Layanan Pengetahuan tentang Covid-19 di Lembaga Informasi. Layanan pengetahuan, 4(1),1-19.

7. ristyawati, aprista. 2020 . efektivitas kebijakan pembatasan sosial berskala besar dalam masa pandemi coronavirus 2019 oleh pemerintah sesuai amanat UUD NRI tahun 1945. Administrative law \& governance journal. 3(2),1-10.

8. Sulaeman, Supriadi. 2020. Peningkatan Pengetahuan Masyarakat Desa Jelantik Dalam Menghadapi Pandemi Corona Virus Diseases 19 ( COVID-19). Judul Pengabdian Undikma, 1(1),12-17.

9. Sudono DS Bambang, Setya A Dhani, Rif H Atiningtyas .2017.gambaran kemampuan berpikir kritis perawat primer dalam pelaksanaan asuhan keperawatan di rumah sakit Islam Surakarta. Jurnal ilmu keperawatan Indonesia.10(1):79-103

10. Sutriyanti, yanti, mulyadi. 2019. Analis faktor2 yg mempengaruhi penerapan berpikir kritis perawat dalam melaksanakan asuhan keperawatan di rumah sakit.Jurnal Keperawatan Raflesia, 24(1), 1-12.

11. Simamora, R. H. (2019). Menjadi perawat yang: ClH'HUY. Surakarta: Kekata Publisher. 
12. Simamora, R. H. (2005). Hubungan Persepsi Perawat Pelaksana Terhadap Penerapan Fungsi Pengorganisasian Yang Dilakukan Oleh Kepala Ruangan Dengan Kinerjanya Diruang Rawat Inap RSUD Koja Jakarta Utara (Doctoral dissertation, Tesis FIK UI, Tidak dipublikasikan). 
